\title{
Innovation to impact in spatial epidemiology
}

\author{
Andrew J. Tatem
}

\begin{abstract}
Spatial epidemiology is a rapidly advancing field, pushing our abilities to measure, monitor and map pathogens at increasingly finer spatiotemporal scales. However, these scales often do not align with the abilities of control programmes to act at them, building a disconnect between academia and implementation. Efforts are being made to feed innovations into government, build spatial data skills, and strengthen links between disease control programmes and universities, yet work remains to be done if goals for disease control, elimination and 'leaving no one behind' are to be met.
\end{abstract}

Keywords: Disease mapping, spatial scales, policy, implementation

\section{Background}

The past couple of decades has seen spatial epidemiology become a major area of activity [1]. Driven by factors such as the increasing use of global positioning systems in disease prevalence surveys, health facility mapping and the collection of genetic data, spatially precise epidemiological data are now becoming more widespread. Additionally, spatial epidemiology continues to be a rapidly growing field, with the mapping of health data, the rising availability of epidemiologically relevant variables from satellites and the continued development of statistical methods. Furthermore, the development of rapid diagnostic tests, the use of mobile phone-based reporting, and the advancement of genome sequencing technology add a new dimension in terms of increases in the frequency and speed of data collection. A feature of the above advancements has been a rising trend within the academic world in the ability to map and understand disease patterns and dynamics at increasingly finer spatial and temporal scales, launching new terms such as 'precision public health' [2]. Where once 'subnational disease mapping' meant moving from national to provincial scales, we can now rapidly uncover household-level patterns in the genetic makeup of pathogens [3] and predict, with some accuracy, the distributions of diseases

Correspondence: a.j.tatem@soton.ac.uk

WorldPop, Department of Geography and Environment, University of Southampton, Highfield, Southampton SO17 1BJ, UK and their vectors at a resolution of kilometres across the globe [4].

Every time we sharpen the lens of data collection and analyses to increasingly finer scales we see substantial heterogeneity. For example, in the case of malaria, the number of annual cases may be counted at district level, with some areas having a far greater number of cases than others. Taking a closer look at the district with the most cases, certain settlements within it are seen to contribute most of the cases [5]. Subsequent mapping within these settlements highlights neighbourhoods with a greater number of cases [6] and, within these, neighbouring households with significantly different case loads [7]. Thus, the message put forward in many spatial epidemiology studies is that through our improved understanding, mapping and analysis at increasingly finer scales, highlighting 'hotspots' [8] or 'coldspots' [9], we can highlight communities left behind, pinpoint cases, measure risks and map transmission in a much more effective, efficient and cost-saving way, facilitating the improved targeting of limited resources.

The potential of these new data streams and methods is substantial, providing tools and insights to tackle diseases across types, endemicity spectra and spatiotemporal scales, and tailoring approaches to needs, whether to stratify risk for endemic diseases or to track down the last few cases to eliminate a pathogen. However, this all needs to be balanced against the ability of over-burdened and under-resourced disease control 
programmes to adopt new methods and act at such fine scales. A national disease control programme that plans, operates and implements at district levels faces major challenges in using and acting on finer scale insights. Additionally, research is often lacking on what scales increase noise, obscure patterns and become cost-prohibitive for action. Geographical Information Systems are becoming increasingly widespread tools for monitoring, mapping and analysing disease data; however, the costs of licenses and training can be prohibitive in some settings. Moreover, while academia races ahead in developing new methods, insights and outputs, these can be slow to filter through to those tasked with controlling and eliminating the diseases. The low uptake and use of risk maps, modelling and 'big data' in national decision-making is evidence of this $[10,11]$. Such a lag has and always will exist; yet, if ambitious global and national goals for disease control, elimination and leaving no one behind' are to be met, there is a need to start closing the gap.

The disconnect between academia and health ministries is often a limiting factor in the uptake of new methods, yet disconnects between academic fields and within government can also present obstacles. Valuable research and investments in precise diagnostics, vaccination tracking and surveillance systems can be undermined by a lack of similar efforts in measuring and mapping populations to provide the important context of denominators at small spatial scales - are the 100 cases of disease ' $\mathrm{X}$ ' identified coming from a population of 1000 or 10,000 ? The phenomenon of vaccination coverage rates of greater than $100 \%$ is common through the use of outdated census counts as denominators [12, 13], while national disease surveys struggle to be representative if reliant on sample frames that are many years old in countries with rapidly changing populations [14].

\section{Conclusions}

The lags in government adoption of scientific innovations in spatial epidemiology as well as disconnects between academia and disease control programmes are being tackled, with many positive examples that point towards recipes for bridging gaps. Links between ministries of health and local universities are being strengthened, training in Geographical Information Systems is becoming more widespread together with the adoption of open-source or tailored systems and dashboards [15], and organisations and funding programmes are focussing on feeding innovations into health systems and national statistics offices, sometimes requiring that modellers be embedded in ministries of health. Further, major funders and implementing partners are increasingly building explicitly applied public health goals into funding proposals; these require ministries of health to be involved and success is judged on uptake and implementation of new methods (e.g. [16]). The problems of inaccurate or missing denominators are being addressed through the integration of survey, satellite and mobile phone data, feeding into dashboards and tracking systems used by ministries of health [17]. While these efforts are gaining traction, they are not quite yet the norm, with academics often still rewarded more for quick-win publications in top journals than for the slower and more political process of engagement in the development of new insights and methods with national programmes to ensure sustained adoption and impact. On the implementation side, workloads and financial constraints often leave no time for learning about new findings and approaches.

These are exciting times for spatial epidemiology research, as the integration of multiple types of spatially referenced data within powerful new methods pushes us to new frontiers of spatial and temporal precision with great potential for impact. However, unless these are built considering the needs, limitations and capacity of those tasked with designing strategies and acting upon them, and unless appropriate incentives exist to facilitate this, the danger is that such work remains as pretty maps in scientific journals, circulating only in academic bubbles.

\section{Acknowledgements \\ Not applicable. \\ Funding \\ AJT is supported by funding from the Bill and Melinda Gates Foundation, Wellcome Trust and Clinton Health Access Initiative.}

Availability of data and materials

Not applicable.

Author's contributions

AJT conceived and wrote the manuscript.

Ethics approval and consent to participate

Not applicable.

Consent for publication

Not applicable.

Competing interests

The author declares that he has no competing interests.

\section{Publisher's Note}

Springer Nature remains neutral with regard to jurisdictional claims in published maps and institutional affiliations.

Received: 28 June 2018 Accepted: 31 October 2018

Published online: 14 November 2018

\section{References}

1. Kirby RS, Delmelle E, Eberth JM. Advances in spatial epidemiology and geographic information systems. Ann Epidemiol. 2017;27(1):1-9.

2. Dowell SF, Blazes D, Desmond-Hellman S. Four steps to precision public health. Nature. 2016;540(7632). https://www.nature.com/news/four-steps-toprecision-public-health-1.21089. Accessed 23 Oct 2018. 
3. Salje H, Lessler J, Endy TP, Curriero FC, Gibbons RV, Nisalak A, Nimmannitya S, Kalayanarooj S, Jarman RG, Thomas SJ, et al. Revealing the microscale spatial signature of dengue transmission and immunity in an urban population. Proc Natl Acad Sci U S A. 2012;109(24):9535-8.

4. Hay SI, George DB, Moyes CL, Brownstein JS. Big data opportunities for global infectious disease surveillance. PLoS Med. 2013;10(4):e1001413.

5. Kangoye DT, Noor A, Midega J, Mwongeli J, Mkabili D, Mogeni P, Kerubo C, Akoo P, Mwangangi J, Drakeley C, et al. Malaria hotspots defined by clinical malaria, asymptomatic carriage, PCR and vector numbers in a low transmission area on the Kenyan Coast. Malar J. 2016;15:213.

6. Seyoum D, Yewhalaw D, Duchateau L, Brandt P, Rosas-Aguirre A, Speybroeck N. Household level spatio-temporal analysis of Plasmodium falciparum and Plasmodium vivax malaria in Ethiopia. Parasit Vectors. 2017;10(1):196.

7. Kreuels B, Kobbe R, Adjei S, Kreuzberg C, von Reden C, Bater K, Klug S, Busch W, Adjei O, May J. Spatial variation of malaria incidence in young children from a geographically homogeneous area with high endemicity. $\mathrm{J}$ Infect Dis 2008;197(1):85-93.

8. Bousema T, Griffin JT, Sauerwein RW, Smith DL, Churcher TS, Takken W, Ghani A, Drakeley C, Gosling R. Hitting hotspots: spatial targeting of malaria for control and elimination. PLoS Med. 2012;9(1):e1001165.

9. Takahashi $\mathrm{S}$, Metcalf $C \mathrm{CE}$, Ferrari MJ, Tatem AJ, Lessler J. The geography of measles vaccination in the African Great Lakes region. Nat Commun. 2017;8:15585.

10. Buckee CO, Cardenas MIE, Corpuz J, Ghosh A, Haque F, Karim J, Mahmud AS, Maude RJ, Mensah K, Motaze NV, et al. Productive disruption: opportunities and challenges for innovation in infectious disease surveillance. BMJ Glob Health. 2018;3(1):e000538.

11. Omumbo JA, Noor AM, Fall IS, Snow RW. How well are malaria maps used to design and finance malaria control in Africa? PLoS One. 2013;8(1):e53198.

12. Brown DW, Burton AH, Feeney G, Gacic-Dobo M. Avoiding the will o' the wisp: challenges in measuring high levels of immunization coverage with precision. World J Vaccin. 2014;4(3):97-9.

13. Cutts FT, Claquin P, Danovaro-Holliday MC, Rhoda DA. Monitoring vaccination coverage: defining the role of surveys. Vaccine. 2016;34(35):4103-9.

14. Thomson DR, Stevens FR, Ruktanonchai NW, Tatem AJ, Castro MC GridSample: an R package to generate household survey primary sampling units (PSUs) from gridded population data. Int J Health Geogr. 2017;16(1):25.

15. Delmelle EM, Zhu HM, Tang WW, Casas I. A web-based geospatial toolkit for the monitoring of dengue fever. Appl Geogr. 2014;52:144-52.

16. Clinton Health Access Initiative. Using Satellite and Cell Phone Data to Eliminate Malaria in Namibia. Data Impact Case Studies; 2015. https:// dataimpacts.org/wp-content/uploads/2015/06/phone-records-track-malaria. compressed.pdf. Accessed 23 Oct 2018.

17. Wardrop NA, Jochem WC, Bird TJ, Chamberlain HR, Clarke D, Kerr D, Bengtsson L, Juran S, Seaman V, Tatem AJ. Spatially disaggregated population estimates in the absence of national population and housing census data. Proc Natl Acad Sci U S A. 2018;115(14):3529-37.

Ready to submit your research? Choose BMC and benefit from:

- fast, convenient online submission

- thorough peer review by experienced researchers in your field

- rapid publication on acceptance

- support for research data, including large and complex data types

- gold Open Access which fosters wider collaboration and increased citations

- maximum visibility for your research: over $100 \mathrm{M}$ website views per year

At BMC, research is always in progress.

Learn more biomedcentral.com/submissions 